\title{
The Blame-Game: The Politicisation of Western and Muslim Sexual Vices
}

\author{
Christoph Marcinkowski*
}

In 2005, the Research Centre of Malaysia's International Islamic University (IIUM) published a study entitled Sexual Identity: Effeminacy among University Students ${ }^{1}$ which features a shocking documentation of male Malay Muslim youths openly engaging in 'cross-gender' dressing and other 'immoral' acts with fellow (male) students on the campus of IIUM - Malaysia's prime institution of Islamic higher education. The following addresses this serious issue which is also closely related to the topic of the present issue of this journal - the present-day ideals and realities of the family institution.

In their introduction, the authors stated (quite appropriately, one would think) that "[h] $\mathrm{h}$ umans are divided into two sexes: males and females. This dichotomy motivates humans to seek cooperation from each other and develop interdependence. Sex is a 'system of binary oppositions' biologically determined and invariant. The qualities of sex are manifested in one or the other way in human behaviour. The most accepted view is that it originated from instinctual characteristics and [is] supplemented with personal qualities of individuals." ${ }^{2}$ They continue by arguing that "Islam [and by extension, as this writer would like to add, Christianity and Judaism] recognizes only two sexes: male and female, and condemns effeminacy and castration, by which an individual does not belong to either sex." 3 To such a condemnation homosexual activities could be added.

Based on the authors' in-depth study one arrives at the conclusion that effeminacy and homosexuality in Malaysia are mainly a Malay affair - and to a somewhat lesser degree an ethnic Chinese and Indian issue. To the mind of this writer, however, what is even more shocking than this already disturbing scenario are the recommendations given by the authors: apart from the usual (and outdated) 're-education schemes', they would like to inculcate 'Islamic values' into the individual concerned. In the view of this writer though such an approach seems to be rather strange as one wonders how those individuals had been admitted at a religious institution of higher learning in the first place and as one would have expected a somewhat more selective approach by the authorities involved. Instead 'softies' (a term constantly and in a quite played-down fashion used by the authors for those students who are yet 'unsure' about their gender) seem to have been treated even in a rather

* Christoph Marcinkowski is Principal Research Fellow and Co-Chair of Publications at IAIS Malaysia. 
accommodating manner by providing them with separate lodging on campus ${ }^{4}$ when one would have expected a different course of action.

Such a rather disturbing setting appears to come within an even more dreadful scenario. Within the last decade or so, Malaysia's capital city Kuala Lumpur appears to have developed into one of Southeast Asia's 'premier' travel destinations for mainly male Middle Eastern and Western 'sex tourists' of any inclination. Anyone visiting Kuala Lumpur's downtown Bukit Bintang or Central Market districts or the ground level of the capital's KLCC Petronas Twin Towers, for instance, will come across (mainly Malay-Muslim) youths annoyingly 'offering' their 'services' to often unsuspicious local and foreign shoppers and visitors. Moreover, in terms of openly operating gay and lesbian venues such as bars and discos, Malaysia seems about to outdo certain other countries in the region which are usually associated with such activities. ${ }^{5}$

Those who nurture fond feelings for Malaysia (like this writer who has been in the country for quite some time) are left in doubt as to how this would reflect on the country's image. Moreover, readers of this journal might also rightly ask how this would blend with the former 'Asian values' agenda or with the circumstance that not too long ago Malaysia has been one of the Muslim world's main critics of 'the West' for the latter's supposed 'immorality' and 'decadence'.

At the same time, we are on an almost daily basis bombarded with 'news' on the supposed 'moral corruption' of 'the West', such as the fact that many Western countries do allow male and female homosexuals to enter into civil law-like marriage arrangements and alike. Indeed, to many practising Muslims (and Christians) this is unacceptable. Moreover, amid all this 'West-bashing' and often politicised 'blame-game' Muslim critics tend often to forget that many westerners themselves do not agree with such a setting and that male homosexual prostitution in Western Europe, for instance, is firmly in the hands of gangs of Arab, Turkish, and other Middle Eastern migrant youths. In addition, what also remains often untold is the circumstance that in the West there exists something known as 'completely straight men', i.e. men who are not interested in any bisexual 'covered operations' - 'operations' which are usually associated, rightly or wrongly, by wider strata in the West with certain other non-western, 'oriental' cultures.

We are thus faced here with a projection of one's own vices into the culture of 'the Other'. What also has become clear is the blatant degree of ignorance and even misinformation of each other's culture. Especially politicians - the 'ultra Right' in the West and certain extremists or populists among the Muslims in the East - tend to use those information deficiencies to mobilise their respective constituencies prior to general elections or in times of internal crises. As, however, has hopefully also become clear just now, 'sexual vices' aren't necessarily something which is peculiar to one particular culture or civilisation. 


\section{Conclusions and Recommendations}

Where are we to go from here? What is perhaps needed is a closer look at one's own ongoing concerns before pointing the finger at 'the Other'. As we have seen above, Malaysia, for instance, is currently facing rather serious issues:

- In general, a somewhat less nonchalant attitude toward social vices and disorders which are unacceptable to both Christianity and Islam would be in place.

- However, both Islam as well as Christianity reject inquisitorial means or activities by vigilantes. Homosexuality and effeminacy should only be seen as a social issue once they start to interfere with traditional values of a nation. No one should be singled out or spied upon. ${ }^{6}$

- What the abovementioned IIUM-study seems also to have revealed is that Malays are less able to cope with modernity and some of the less fortunate influences brought by globalisation. Contrary to the views of the authors, however, this appears not to be due to a supposed lack of religious education - Malaysia is already featuring to the mind of some observers too many disconnected Islamic educational institutions - but because of the narrow perspective of the provided teaching.

- Homosexuality and effeminacy in Malaysia are not something which has been inherited from the 'decadent West' and brought into the country by the 'evil white man' but appear to be rather 'home-grown'. Moreover, those two phenomena have also been quite frequent in the Arab, Persianate, and Turkic literatures throughout the last thousand years or so. ${ }^{7}$ Not every 'beloved' mentioned on the pages of Persian poetry, for instance, is necessarily to be identified with God - especially if that 'beloved' is described with all the trappings of an adolescent male.

- The initially referred to IIUM study has merely described a growing problem but has not offered any practical solutions, especially in terms of the issue why homosexuality and effeminacy appear to be a problem that is mainly faced by Malay-Muslim youths. The Malaysian government is therefore urged to commission more comprehensive studies into the issue - preferably carried out also (but not only) by academics from outside the country in order to ensure objectivity.

- The reasons behind the comparatively high divorce-rate among the Malays too need to be investigated more thoroughly, in particular within this context. The research should also emphasise the 'home-grown' origin of the issue in order to come up with realistic and practicable solutions - solutions that go perhaps beyond the usual one-size-fits-all advice of "do your prayers" and "don't watch 
too much HBO". A good beginning would be a closer investigation into the notorious 'dorm culture' of local universities and colleges.

- Supposed or real 'sexual vices' then should not be politicised as the fault of 'the Other' - as we have just seen, such an approach could easily backfire.

- And finally, perhaps it would be time to review Malaysia's 'Islam policies' of the past decades which appear to have focused on mere externals.

\section{Notes}

1. Noraini Mohd Noor, Jamil Farooqi, Ahmad Abd. Al-Rahim Nasr, Haziran bin Mod Noon, and Shukran Abdul Rahman, Sexual Identity: Effeminacy among University Students (Kuala Lumpur: International Islamic University Malaysia, 2005).

2. Ibid., 1 .

3. Ibid., 7 (emphasis added).

4. Information provided to the author by IAIS Assistant Research Fellow Abdul Karim Abdullah (Leslie Terebessy).

5. For an update on what is currently really going on in the country in this regard see Jerome Kugan and Pang Khee Teik (eds), Body 2 Body: A Malaysian Queer Anthology (Petaling Jaya [Malaysia]: Matahari Books, 2009, 2nd ed.).

6. See, for instance, Qur'ān 49:12: "O ye who believe! Avoid suspicion as much (as possible): for suspicion in some cases is a sin: And spy not on each other behind their backs. Would any of you like to eat the flesh of his dead brother? Nay, ye would abhor it [...]. But fear Allah. For Allah is Oft-Returning, Most Merciful."

7. See, for instance, Stephen Murray and Will Roscoe (eds), Islamic Homosexualities: Culture, History, and Literature (New York: New York University Press, 1997); Samar Habib (ed.), Islam and Homosexuality, 2 vols (New York: Praeger, 2009); and Brian Whitaker, Unspeakable Love: Gay and Lesbian Life in the Middle East (Berkeley CA: University of California Press, 2006). 